\title{
Dadžare - japonský kalambúr a jeho výzkumný potenciál
}

\author{
Mgr. Jiří Matela, M.A., Ph.D. \\ Filozofická fakulta, Masarykova univerzita \\ $\bowtie$ 365342@mail.muni.cz
}

Orientalia Antiqua Nova XXI

ISBN 978-80-261-1039-2

Západočeská univerzita v PIzni, 2021

https://doi.org/10.24132/ZCU.2021.10392-60-77 


\section{Abstract}

Dajare - Japanese pun and its research potential The present paper introduces dajare as a Japanese form of puns, i.e. utterances with multiple meanings based on a wordplay. Dajare is chosen as a minimal text with a potential of humorous effect, thus a promising starting point for a research of humor and laughter from perspectives of cultural anthropology and cognitive linguistics. While the ability to make puns with the use of the Chinese script in Japan is historically well documented in the form of gisho, the concept of dajare is traced to the realms of the poetic forms of haikai no renga, zappai etc. In modern Japan, dajare is often regarded rather negatively as "old men's joke" (oyaji gyagu), mainly due to its separation from the tradition of poetic wit. Nevertheless, several areas of the use of dajare are presented and some principles of its most common form are discussed from the linguistic point of view. The paper ends with two main proposals for further research into Japanese puns: Research in the communicative, textual and discourse functions of dajare (humorous effect as the main goal is questioned) and in the relation of puns and linguistic creativity from the perspective of construction grammar. 


\section{Úvod ${ }^{1}$}

Moderní zkoumání humoru představuje dynamicky se rozvíjející oblast akademických aktivit, a to mimo jiné díky následujícím faktorům: a) Nová poznání v této oblasti Ize vztáhnout k obecné rovině poznání člověka a kultury, současně však umožňuji zkoumání partikulárních specifik, jež jsou kulturně vázána na konkrétní společenství; b) Objekt zkoumání svojí povahou nutně vyžaduje interdisciplinární přistup, který Ize v humanitních a společenských vědách dnes již považovat za jeden z hlavních teoreticko-metodologických proudů. $\mathrm{K}$ novému zacílení na obecnějši psychologické a kognitivní mechanismy produkce a percepce (nejen) verbálního humoru vybízí také rozvoj empirického výzkumu na poli tzv. kognitivní lingvistiky, ${ }^{2}$ která je sama ze své podstaty orientována interdisciplinárně. $\mathrm{K}$ přesvědčení, že navzdory potenciálně obecným předpokladům $\mathrm{k}$ produkci humoru existuji kulturně specifické normy, nás může přirozeně vést běžná subjektivní zkušenost komunikace s osobami odlišného kulturního pozadí. Podobná zkušenost však sama o sobě jen stěži poskytne návod, jak k fenoménu humoru přistoupit akademicky, a to přinejmenším proto, že zmíněný objekt studia je mnohorozměrný a nesnadno vymezitelný.

Cílem tohoto príspěvku je představit specifický textový žánr japonského jazyka, tzv. dadžare. Jedná se o kulturně ukotvené kalambúry, slovní hříčky, které pokládáme za rozsahem nejmenší textový útvar, s nímž lze asociovat komické efekty. Právě z toho důvodu jej pokládáme za vhodný vstupní bod při zkoumání specifik japonského verbálního humoru. Nejprve stručně přibližíme obecná východiska kalambúrů na príkladech jazyků, jež jsou čtenáři bližši (čeština, angličtina), abychom následně představili

\footnotetext{
${ }^{1}$ Pro přepis japonských výrazů je v celém textu použita česká transkripce japonštiny. Všechny překlady jsou dílem autora.

${ }^{2}$ Brône et al. 2006.
} 
jejich japonskou variantu, tj. dadžare. $V$ dalších oddílech pak nastíníme některé historicky doložené príklady praxe slovních hříček, objasníme etymologii výchozího japonského pojmu a načrtneme některé zdroje kalambúrů $v$ japonském komunikačním prostoru. Dále se pokusíme shrnout vybrané formální principy vzniku japonských kalambúrů, mimo jiné s přihlédnutím $\mathrm{k}$ fonologickému systému japonštiny. $\mathrm{V}$ závěru nabídneme několik perspektiv dalšího výzkumu, a to skrze témata, $\mathrm{k}$ nimž právě zkoumání kalambúrů podle nás vybízí.

\section{Pojem kalambúr}

Výraz „kalambúr“ v současné češtině nebývá uživán s výraznou frekvencí. ${ }^{3}$ Do češtiny se dostal z francouzštiny, přičemž Slovník cizích slov uvádí též dřívější způsob zápisu "calembour“." Po obsahové stránce je Klimeš (1994) stručný, uvádí pouze „slovní hřička“. O něco podrobnější je on-line slovník cizích slov pod doménou abz.cz, kde je uvedeno „slovní hřička založená na zvukové podobnosti významově různých slov". ${ }^{5}$ Relativně nejpodrobnějším z encyklopedických hesel on-line je v tomto ohledu heslo Slovní hřička (kalambúr) v Novém encyklopedickém slovníku češtiny: ${ }^{6}$

„Prostředek aktualizace výrazu vybudovaný bud' na zvukové (řidčeji grafické) blízkosti slov (slovních spojení) s rozdílným významem, nebo na obnovení původního významu, který se významovým posunem slova setřel.“

\footnotetext{
${ }^{3}$ Český národní korpus uvádi 0,02 výskytu na milion slov.

${ }^{4}$ Klimeš 1994, 341.

${ }^{5}$ Pojem kalambúr. 30. 5. 2021. https://slovnik-cizich-slov.abz.cz/web.php/slovo/ kalambur-calembour-kalambur.

${ }^{6}$ Jelínek a Vepřek 2017.
} 
Za pozornost stojí také následující poznámka, tedy že „účelem slovní hříčky je dosáhnout humorného účinku. "7 Tvrzení o účelu dosažení humorného účinku Ize $v$ tuto chvíli pokládat za spekulativní, z konkrétních příkladů však je patrné, že vhodně formulovaný kalambúr dokáže aktualizovat nejen dva odlišné významy, ale i více.

1) Kozel polyká meče.

2) Koukal sem na mě sýček.

3) Jedli nahoře bez holí.

Příklad 1) Ize asociovat s představou kozla polykajíciho sečné zbraně, ale i s představou kozla vydávajícího při polykání typický zvuk mečení. Výraz "meče“ tak asociuje dvě homonyma - substantivum v roli prímého předmětu a slovesný přechodník $\checkmark$ roli příslovečného určení. Příklad 2) je kalambúrem především $\checkmark$ mluvené podobě (s různými významy vázanými na různé pozice slovního přízvuku). Příklad 3) pak k interpretaci nabízí hned několik různých významů skrze potenciální homonymii více vyskytujících se slov (či slovních spojení).

Podobně jako v češtině funguji kalambúry např. také v angličtině (pod pojmem pun). Definice ateismu z pera komika George Carlina (1937-2008) je postavena na fonologické blízkosti výrazů profit (zisk) a prophet (prorok) a na ustálenosti spojení non-profit organization (nezisková organizace).

4) Atheism is a non-prophet organization. ${ }^{8}$

${ }^{7}$ Pojem kalambúr. 30. 5. 2021. https://slovnik-cizich-slov.abz.cz/web.php/slovo/ kalambur-calembour-kalambur.

${ }^{8}$ GoodReads. 30. 5. 2021. https://www.goodreads.com/quotes/11959-atheism-is-a-non-prophet-organization. 
Kalambúr může být vystavěn na variaci v segmentaci, tj. v hranicích slov (srov. též př. 2) a pracovat s výrazy, jež nejsou součástí lexikonu, byt nepostrádají interpretovatelnost:

5) Infinity is not in finity.

Z hlediska prezentace bývá pak nezřídka součástí jednoduché dialogové struktury otázky a odpovědi:

6) Otázka: Why can a man never starve in the Great Desert? Odpověd: Because he can eat the sand which is there. ${ }^{9}$

V neposlední řadě Ize uvést príklady „multimodálních“ kalambúrů, které spojují verbální aspekt $s$ grafickou reprezentací jednoho z významů. Např. emblém 148. stíhací letky Arizonské vzdušné národní gardy doplňuje heslo Kickin' ass obrázkem ko-

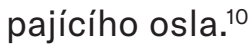

Není překvapivé, že prostředky pro tvorbu kalambúrů mohou být $v$ různých jazycích různé, především s přihlédnutím ke specifickým možnostem ortografickým. Přesto Ize konstatovat, že je to právě pojem dadžare, který $v$ japonštině odpovídá výše představenému pojmu kalambúr (resp. anglickému pun). Následující prríklady 7)-9) jsou převzaty z průběžně aktualizovaného žebřičku nejpopulárnějších kalambúrů na webové stránce DajareStation:11

\footnotetext{
${ }^{9}$ Kalambúr je postaven na fonologické blízkosti spojení substantiva sand (písek) se vztažným zájmenem which (který) a substantiva sandwich (sendvič).

${ }^{10}$ Výraz ass kromě osla označuje též „zadek“ (v britské angličtině mu odpovídá výraz arse), který může být „nakopnut“.

${ }^{11}$ DajareStation. 31. 5. 2021. https://dajare.jp. K uvedenému datu byly pozice vybraných kalambúrů 34 (kalambúr 7), 5 (kalambúr 8) a 18 (kalambúr 9).
} 
7) かなりヤバイ客がカナリヤ売却

Kanari jabai kjaku ga kanarija baikjaku

(Značně hustej zákazník prodává/zbavuje se kanárka)

8)まあ、クンニ中のマー君にチュウ

Má, kunničú no Má-kun ni čú

( $\mathrm{Nu}$, během orálku Masahirovi ${ }^{12}$ pusinku)

9) 有名クラブで、You make love.

Júmei kurabu de, jú meiku rabu.

(Ve známém klubu se pomiluješ.)

Příklad 7) ilustruje princip blízké homofonie - slabičná sekvence se opakuje - význam celé konstrukce je však jednoznačný díky zápisu. Opakování slabičné sekvence (s odlišným postavením hranic slov) je prítomno také v príkladech 8) a 9) (jedná se o víceméně jednotný vzorec kalambúrů na zdrojové webové stránce), poslední príklad pak navíc pracuje s adaptací jednoduché anglické fráze na fonologický systém japonštiny.

O formálních zdrojích kalambúrů $v$ japonštině se ještě bliže zmíníme v oddíle 5 . $V$ následujícím oddíle představíme etymologii pojmu dadžare a některé vybrané príklady slovních hříček v nejstarších dochovaných japonských zdrojích.

\section{Historie slovních hříček a etymologie pojmu dadžare}

Tvorba kalambúrů je populárním způsobem tvůrčího uživání jazyka mnoha současných Japonců. Interpretace i tvorba slovních hřiček prritom předpokládá schopnost metajazykového

\footnotetext{
${ }^{12}$ Důvěrným Má-kun se běžně odkazuje k osobě známého hráče baseballu jménem Masahiro Tanaka (nar. 1988).
} 
nahližení na jazyk a jeho výrazové prostředky. ${ }^{13}$ Doklady specifických zacházení s jazykovými formami, které jsou originálním způsobem integrovány do textu, však Ize pozorovat již v nejstarších literárních památkách. Jamaguči (2006) zmiňuje příklady tzv. gišo 戯書 - specifického uživání čínských znaků pro metajazykové hřičky v japonském textu - v nejstarší sbírce japonské poezie Man'jóšú z 8 . století: ${ }^{14}$

10) 若草の新手枕をまきそめて夜をや隔てむ三八十二あらなくに (Poté, co jsem si vyměnil slib se ženou jako jarní tráva, nemohu vydržet byt jen jediný večer bez ní. Vždyṫ je tak k uzoufání půvabná!)

11）見るごとに恋はまされど色に山上復有山ば人知りぬべみ (Když vidím, jak mi žena při odchodu pomáhá upravit rukávy kabátce, zaplaví mne stesk. Dám-li však těmto svým citům průchod, všimnou si toho všichni kolem...)

Podtržený výraz v básni č. 2542 (zde jako př. 10) sestává z čínských znaků pro číslice 2, 8, 10 a 1 (v moderní japonštině ni, hači, džú a iči). Má se však číst /nikuku/. K danému čtení vede následující rébus: $2-((8 \times 10)+1) \rightarrow 2-81$. Číslo 2 se vysloví /ni/, číslo 81 má být interpretováno jako „9 9 9“, přičemž devítka má sinojaponskou výslovnost /ku/, tedy 2-9-9 (nikuku).

Báseň č. 1787 (zde jako př. 11) operuje s popisem grafické formy čínského znaku. Pro zápis cílového výrazu ideba se běžně uživá znaku 出. Sekvence 山上復有山 pak obsahově symbolizuje propozici „nad horou je ještě jedna hora“. Znak 出 tak připomíná posazení znaku pro horu 山 na stejný znak 山, tj. 山 + 山 $\rightarrow$ 出.

\footnotetext{
${ }^{13}$ Viz např. Koike 2010, 15-17.

${ }^{14}$ Básně jsou uvedeny v modernizované formě zápisu, který již využivá kombinaci čínských znaků s moderní podobou japonské slabičné (resp. moraické) abecedy hiragana. České překlady A. V. Límana z let 2003 a 2007 klíčové výrazy nereflektují.
} 
Jiné přiklady gišo v nejstarších dochovaných opisech sbírky Man'jóšú zahrnuji zápis onomatopoií, a kromě metajazykových schopností editorů sbírky tak mohou sloužit jako doklad o formálních aspektech lexikálních prostředků symbolizujících zvuky zviřat v době kompilace díla.

Etymologie pojmu dadžare nicméně sahá až do přelomu 17. a 18. století, tedy do éry Genroku, kdy v prostředí rozvijející se měštanské kultury center jako Ósaka či Edo (dnešní Tokio) získává na popularitě kratochvilná praxe kolektivní tvorby tzv. haikai no renga - „hravé řazené básně“. Kolektivní řazení jednotlivých slok, při němž na sebe jednotliví účastníci vzájemně reagují, vyžaduje značnou dovednost, nebot̉ obsahové i formální aspekty poetické tvorby jsou v tomto období již výrazně ovlivňovány několikasetletou tradicí norem japonského básnictví, z něhož haikai no renga čerpá. Řada účastníků kolektivního skládání řazených básní přitom nachází zálibu a potěšení především ve cvičení doplňování slok k zadanému trojverší (tzv. maekuzuke), při němž Ize kreativně tvořit slovní hřičcy či zajímavé intertextuální asociace. $Z$ toho následně vzniká nová forma hravého veršování, tzv. zappai 杂倠排, které na rozdíl od prírodně lyrické formy hokku (dnes známe jako haiku) nemá potřebu dodržovat imperativ sezónních slov kigo či jiných formálních požadavků forem inspirovaných zenovou estetikou. ${ }^{15}$

Právě v rámci zappai je pak vysoce ceněn prvek tzv. šare (dnes nejčastěji zapisovaný pomocí foneticky přiřazených znaků 酒落, původně však spíše s užitím znaku 戯), ${ }^{16}$ který označuje (dů)vtip, trefnost, břitkost, ale současně také vytříbenost, kultivovanost a stylovost. S tím, jak nově vzniklá forma kratochvíle získává na

\footnotetext{
${ }^{15}$ Pro novou formu se užívá i dalších označení, např. kjóhai 狂排 aj. Upuštěním od nutnosti návazného řazení slok a osamostatněním úvodního trojverší s převážně satirickým obsahem následně vzniká forma tzv. senrjú 川柳.

${ }^{16}$ Suzuki, 1959, 882-883.
} 
popularitě mezi širokými vrstvami obyvatelstva, dochází nutně $\mathrm{k}$ jisté degradaci důrazu na kultivovanost a vytříbenost, pěstovanou pod vedením profesionálních básníků a hodnotitelů. Laciné či vulgární slovní hřičky pak jsou označovány výrazem s předponou da- 駄, čímž vzniká pojem dadžare 駄酒落. ${ }^{17}$

$S$ rozvojem modernizace $v$ Japonsku od 2. poloviny 19. století, a především pak v období po 2 . světové válce postupně zaniká specifická lidová subkultura, již je pojem šare nedílnou součástí. Tím také dochází $k$ odtržení šare (a potažmo dadžare) od původního tvůrčiho zázemí hravého kolektivního veršování haikai. $V$ důsledku toho v současnosti mnoho Japonců (především mladši generace) nahliži na kalambúry dadžare se značným despektem jako na něco staromódního a odkazuji k nim pojmem ojadži gjaku オヤジギャグ („fotrovské vtípky“). Jejich užití pak často bývá hodnoceno jako „cumetai“ („chladné, nevtipné“), tedy bez kýženého humorného účinku.

\section{Dadžare v současném Japonsku}

Navzdory jistým nelichotivým asociacím, které s sebou kalambúry v současném Japonsku mohou nést, existuje celá řada oblastí a komunikačních prostředí, v nichž dadžare nachází své pevné místo. Nejsnáze dostupné jsou přitom právě skrze na dadžare se specializující zájmové skupiny, jež působí především on-line. 18 1. zárí 2014 byla založena Japonská asociace rozvoje dadžare (Nihon dadžare kacujó kjókai), která si za hlavní cíl svého působení klade pozitivní rozvoj mezilidských vztahů skrze šíření dadžare..$^{19}$ Sdružuje členy bez ohledu na pohlaví, věk či

\footnotetext{
${ }^{17}$ Slovní hřičky jsou současně označovány i jinými pojmy, např. džiguči 地口 aj. ${ }^{18}$ Příkladem je výše zmíněná stránka DajareStation, https://dajare.jp.

${ }^{19}$ Ippan šadan hódžin Dadžare kacujó kjókai. 30. 5. 2021. https://www.dajare-zukai.jp/about/.
} 
vzdělání, pořádá soutěže ve tvorbě kalambúrů a podporuje jejich užívání v širokém spektru běžných činností. Dadžare jsou přirozenou součástí vystoupení celé řady stand-up komiků a komických dvojic v zábavních pořadech typu owarai bangumi. Duo Anonenone tvořené Kuniakim Šimizuem (nar. 1950) a Noburóem Haradou (nar. 1951) si v 70. letech minulého století získalo značnou popularitu mimo jiné sérii komických písní založených právě na kalambúrech.

Zajímavým přikladem využití efektu kalambúrů v marketingu je série krátkých televizních reklamních spotů Tanoméru firmy Ócuka šókai, která se specializuje na prodej a servis širokého spektra kancelářského vybavení. Jeden spot je napřiklad postaven na následujícím dadžare:

12) お、トナーがない。頼まないトナー。

$O$, toná ga nai. Tanomanai to ná.

(Oh, nemáme toner. Musíme si zažádat...)

Příklad 12) pracuje $s$ homofonii $z$ angličtiny přejatého výrazu toná (toner) a spojení modálních partikuli v konstrukci pro vyjádření nutnosti, tedy to a ná.

Na dadžare Ize narazit i $v$ reklamách automobilek Hino či Nissan, výrobců potravin, a Ize říci, že jde o obecně populární výrazový prostředek v televizní či tištěné reklamě přinejmenším od 90 . let.

V souvislosti s výskytem dadžare pritom nelze opomenout ani jeho laické či spontánní užívání v běžné komunikaci. Je přirozené, že pro svůj „humorný účinek“ je užívání kalambúrů vázáno především na prostředí důvěrných vztahů mezi účastníky komunikace, kde může plnit funkci posilování pocitu vzájemné přináležitosti k dané sociální skupině (tzv. uči), aniž by zásadním 
způsobem ohrozil veřejný obraz mluvčiho či adresáta. Typickým prostředím výskytu dadžare tak mohou být kolektivní večírky, posezení v restauracích, oslavy apod., při nichž mohou být dadžare součástí nejen spontánních reakcí v aktuální komunikaci, ale též odlehčujícím prvkem jinak vážnějších proslovů.

\section{Vybrané principy tvorby a vzniku dadžare}

Snaha o propagaci dadžare $v$ běžné komunikaci v Japonsku se projevuje mimo jiné knižními publikacemi, $v$ nichž kromě hotových kalambúrů figuruji také návody, jak je tvořit. Nagata nabízí jeden takový návod ve čtyřech krocích: ${ }^{20}$

1. Napsat si výchozí slovo na papír. (Pro ilustraci volí slovo surippa - „nazouváky“.)

2. Hledat případná další slova ukrytá v napsaném slově. (Ve slově surippa Ize objevit výrazy suri - „zloděj“ a rippa - "nádherný“.)

3. Spojením nalezených slov vytvořit ucelenou výpověd’. (Důraz je přitom kladen na vhodný rytmus výsledného textu.)

13)スリのスリッパ、とても立派

Suri no surippa, totemo rippa

(Zlodějovy nazouváky, opravdu nádherné)

V posledním čtvrtém kroku pak vybízí k záměně jednoho znaku (slabiky) ve výchozím výrazu pro získání fonologicky podobného slova a dosažení většího účinku celé promluvy (např. změnou surippa na surippu - „,spodnička“). Výsledná výpověd' nemusí být nutně vázána na určitou komunikační situaci - autor kalambúru

${ }^{20}$ Nagata 2018, 22-23. 
tedy primárně prokazuje svoji schopnost metajazykové práce s jazykovými formami.

Z příkladů je patrné, že jedním z hlavních zdrojů a předpokladů tvorby kalambúrů $v$ japonštině je fonologický systém japonského jazyka. Ten je tvořen relativně omezeným inventářem 122 slabičných fonémat se strukturou otevřené slabiky (tj. CV nebo CjV) ${ }^{21}$ a jednou moraickou nazálou. Slabičná fonémata jsou tvořena jedním z pěti vokálů: /a/, /i/, /u/, /e/ a /o/.22 Omezený fonematický inventář utváři přirozené podmínky pro vznik homofonie, která je v japonštině obecně běžným jevem. Níže proto představíme některé vybrané typy japonských kalambúrů ve vztahu právě k homofonii.

\section{Segmentační homofonie}

Tento typ dadžare staví na čisté homofonii slov. Ta mohou přitom figurovat v různých syntaktických rolích.

14) 蛙の子もかえる

Kaeru no ko mo kaeru

(Dítě žáby je také žába. / Dítě žáby také půjde domů.)

15) 校長先生絶好調

Kóčó sensei zekkóčó

(Ředitel školy je hodně v poho.)

\section{Nesegmentační homofonie}

Tento typ dadžare staví na opakování určité sekvence fonémat, která při interpretaci obsahu vyžadují odlišnou segmentaci každé sekvence s ohledem na lexikální či gramatickou stavbu.

\footnotetext{
${ }^{21} \mathrm{C}=$ konsonant, $\mathrm{V}=$ vokál, $\mathrm{Cj}$ = palatalizovaný konsonant.

${ }^{22}$ Zde uvedený popis je vztažen ke standardní tokijské variantě moderní japonštiny.
} 
16)よくできた内容ですが、欲で污いようです。23

Joku dekita naijó desu ga, joku de kitanai jó desu.

(Je to dobře udělaný obsah, ale je jaksi zašpiněný chtíčem.)

Tento běžný typ dadžare ilustruji i výše uvedené příklady 7), 8), 9) a 12).

\section{Blízká homofonie}

Návazná opakující se sekvence fonémat je jen minimálně alterována. Může jít o alteraci vokálu či konsonantu (př. 17) o vložení specifických fonémů (tokušu onso, př. 18) ${ }^{24}$ či o metatezi (přesmyčku v lineárním pořadí fonémat, př. 19).

17) トイレに行っといで

Toire ni ittoide

(Zajdi si na záchod.)

18)布団が吹っ飛んだ

Futon ga futtonda

(Pokrývka odletěla/byla odfouknuta.)

19) ダジャレを言うのは誰じゃ

Dadžare o iu no wa dare dža

(Kdo tu řekne kalambúr?)

V příkladu 17) je blízká homofonie tvořena opozicí verberanty $/ \mathrm{r} /$ ve slabice /re/ a znělé plozivy /d/ ve slabice /de/. V príkladu 18) je opozice fonémat /fu-to-N/ a /fu-Q-to-N/ opět př́kladem blízké homofonie. ${ }^{25} \mathrm{~V}$ příkladu 19) je sekvence fonémat slova

${ }^{23}$ DajareStation. 31. 5. 2021. https://dajare.jp.

${ }^{24}$ Mezi specifické fonémy se řadí tzv. sokuon - foném zdvojující konsonant (resp. moraické obstruenty), tzv. čóon - foném prodlužující vokál o hodnotu jedné móry a tzv. hacuon - moraická nazála.

${ }^{25}$ Symbol /N/ označuje moraickou nazálu, symbol /Q/ pak moraický obstruent vzniklý geminací navazující konsonanty (zde /t/). 
dadžare, tj. da-dža-re, alterována sekvencí stejných fonémat $v$ odlišné posloupnosti, tj. da-re-dža. Všechny uvedené zdroje kalambúrů jsou v souladu s výchozí fonologickou strukturou japonského jazyka. Pro rozšiřrení kombinačních možností se také nezřídka užívá prostředků příznakových dialektů či sociolektů.

Z hlediska textového zapojení kalambúrů Ize $v$ japonštině pozorovat podobné jevy, jako v češtině či angličtině. Dadžare Ize konstruovat jako izolované výpovědi, Ize je však také vložit do vtipných dialogů či hádanek.

20) Otázka: 宇宙でお腹が空かないのはなぜ?

Učú de onaka ga sukanai no wa naze?

(Proč člověku ve vesmíru nevyhládne?)

Odpověd: くうきがないから。 ${ }^{26}$

Kúki/Kuu ki ga nai kara.

(Nemá tam vzduch/chut žrát.)

Kalambúr v odpovědi př. 20) stojí na homofonii sekvence kúki 空気, „Vzduch“ a sekvence kuu ki 食う気, „chut žrát/jíst“.

\section{Závěr}

Kalambúry (včetně japonských dadžare) jako minimální výpovědi s potenciálně humorným účinkem představují výzvu nejen pro teorie humoru, ale i pro obecnějši teorie jazyka. $V$ teoriích tzv. konstrukční gramatiky je na jazykové prostředky nahliženo jako na specifický typ znalosti symbolizace konceptuálního obsahu (s různou měrou konkrétnosti či schematičnosti) pomocí prostředků výrazových (opět se skalární schematičností). Konstrukty, jež formálně či obsahově vybočuji z ustálených konstrukcí,

${ }^{26}$ Dadžaremon. 31. 5. 2021. http://amaebiuniko.web.fc2.com/a_o.html. 
bývají nahliženy jako produkty specifického typu kreativity. ${ }^{27}$ Hoffman a další rozlišují mezi tzv. F-kreativitou a E-kreativitou. Zatímco první („fixni“) spočivá v produkci nových výpovědí, jež využívají pouze existujících symbolických prostředků (a odpovídá tak běžné systémové produktivitě), druhá („extensivni“) $\checkmark$ nějakém ohledu, obsahovém či formálním, alteruje existující konstrukce a je tak mimo jiné zdrojem prirozeného vývoje jazykového systému jako celku. Vyvstává pak otázka, k jakému typu kreativity vztáhnout právě nové kalambúry, o jaký typ „znalosti“ se $v$ prípadě kalambúrů jedná.

Aparát kognitivně orientované lingvistiky se pritom pro analýzu slovních hřiček vhodně nabízí, nebơ jeho cílem je mj. popisovat kognitivní mechanismy, jež jsou aktivní při uživání a interpretaci jazyka. Je tak zcela namístě klást si otázku, jakými teoretickými modely Ize zachytit mechanismy uživání právě kalambúrů, a jak dané modely empiricky ověřovat. Tato otázka má i své historické opodstatnění. Právě snahy teoreticky uchopit specifické a z jistého úhlu pohledu periferní jazykové útvary vedly v 60. letech badatele jako Charles Fillmore či Paul Kay k výzkumům, jejichž přimým důsledkem jsou i dnešní mainstreamové teorie konstrukční gramatiky. Jak poukazuje mj. Evans (2015), výzkum kognitivních mechanismů verbálního humoru může mít zásadní prínos pro poznání obecnějších mechanismů jazykového významu. $V$ tomto ohledu se přistupy kognitivní lingvistiky jeví slibnějšími než např. přistupy interpretativní.

Je důležité zkoumat kalambúry $v$ jejich konkrétním uživání. $\checkmark$ 2. oddílu tohoto přispěvku jsme tvrzení o účelu slovních hřiček vyvolat humorný účinek označili za „spekulativni“ právě proto, že vychází z interpretativního pohledu na užívání jazyka. Kalambúry Ize pritom nacházet i v situacích, v nichž je komický

${ }^{27}$ Hoffman 2018. 
efekt bud' problematické identifikovat, nebo je prímo nežádoucí. V japonské reklamě na čaj výrobce Kirin z roku 2006 herečka Nanako Macušima něžným šepotem pronáší dadžare:

21)苦い濃いより、甘い濃い。

Nigai koi jori, amai koi.

(Raději sladkou plnost než hořkou plnost.)

Kalambúr je postaven na homofonii slov koi 濃い - „plnost (chuti)“ a koi 恋 - „láska“ a na metaforickém užití adjektiv nigai - „hořký“ a amai - „sladký“, jež mohou být vztažena nejen k popisu chutového zážitku (z čaje), ale i k popisu emoční zkušenosti ze zamilovanosti. Přestože není pochyb o tom, že cílem zmíněného reklamního spotu je zaujmout diváka a vzbudit $v$ něm touhu koupit si inzerovaný čaj (tj. iniciovat specifickou emoční odezvu), pokládáme za problematické případné tvrzení, že cílem užitého dadžare bylo v tomto prípadě vyvolat humorný či komický účinek. Dadžare tedy zjevně mohou být nositeli humoru, zůstává však otázkou budoucího zkoumání, jaké další komunikační a sociální funkce plní.

Na tomto místě Ize shrnout, že dadžare v japonštině a kalambúry obecně představuji doposud málo zmapovanou výzvu pro teorii jazyka a jazykové kreativity. Jejich výzkum přitom může přispět nejen k mapování jazykově (a tedy kulturně) specifických jevů, ale i k poznání mechanismů významů v procesu porozumění a lidské komunikace. 


\section{Literatura}

Brône, Geert, Kurt Feyaerts a Tony Veale. 2006. „Introduction: Cognitive linguistic approaches to humor." Humor - International Journal of Humor Research 19-03: 203-228.

Evans, Vyvyan. 2015. „How a joke can help us unlock the mystery of meaning in language." On-line: December 15, 2015. 31. 5. 2021. https://theconversation.com/how-a-joke-can-help-usunlock-the-mystery-of-meaning-in-language-51365.

Hoffman, Thomas. 2018. "Creativity and Construction Grammar: Cognitive and Psychological Issues." De Gruyter, online: September 4, 2018. 31. 5. 2021. https://doi.org/10.1515/ zaa-2018-0024.

Jamaguči, Nakami. 2006. Nihongo no rekiši [Dějiny japonského jazyka]. Tokio: Iwanami šoten.

Jelínek, Milan a Jarmil Vepřek. 2017. „Slovní hřička.“ In Czech Ency - Nový encyklopedický slovník češtiny. 30. 5. 2021. https://www.czechency.org/slovnik/SLOVNÍ HŘíčKA.

Klimeš, Lumír. 1994. Slovník cizích slov. Praha: Státní pedagogické nakladatelství.

Koike, Seidži. 2010. Úvod do gramatiky moderní japonštiny. Brno: Tribun.

Nagata, Mikako. 2018. Warau no dare dža Dadžare asobi [Kdo že se to tu směje? Hrátky s kalambúry]. Tokio: Čóbunša.

Suzuki, Tózó. 1959. Kotoba asobi džiten [Lexikon jazykových hrátek]. Tokio: Tókjódó šuppan. 